\title{
Pemberdayaan Masyarakat Melalui Pemanfaatan Sampah Anorganik Menjadi Produk Kerajinan yang Bernilai Ekonomis
}

\author{
Ambar Tri Ratnaningsih', David Setiawan'2, Latifa Siswati ${ }^{3}$ \\ 1Program Studi Kehutanan, Fakultas Kehutanan, Universitas Lancang Kuning \\ 2Program Studi Agribisnis, Fakultas Pertanian, Universitas Lancang Kuning \\ ${ }^{3}$ Program Studi Teknik Elektro, Fakultas Teknik, Universitas Lancang Kuning \\ *e-mail: ambar@unilak.ac.id¹, latifasiswati@unilak.ac.id², dsetia@unilak.ac.id³
}

\begin{abstract}
Inorganic waste is a type of waste that is difficult to decompose naturally by microorganisms. Inorganic waste processing is carried out by collecting, disposing and transporting it to the final disposal site (TPA). There needs to be an effort to utilize inorganic waste, especially plastics, into useful products. People in Limbungan Village, Rumbai Pesisir District, Pekanbaru City already have a waste bank, but the benefits have not been felt by the community because inorganic waste is still being disposed of. There is a need for efforts to socialize and educate the public to process inorganic waste into handicraft products that have economic value. The method is carried out by educating the public about waste processing in general and demonstrating the use of plastic waste into handicraft products. After the counseling was carried out, the community had knowledge about waste management in general and skills in processing plastic waste into handicraft products such as bags, candy containers that were suitable for use and worthy of sale.
\end{abstract}

Keywords: inorganic waste, plastics, handicrafts

\begin{abstract}
Abstrak
Sampah anorganik merupakan jenis sampah yang sukar terurai secara alami oleh mikroorganisme. Pengolahan sampah anorganik dilakukana cara mengumpulkan, membuang dan mengangkut ke tempat pembuangan akhir (TPA). Perlu adanya upaya pemanfataan sampah anorganik terutama plastik menjadi produk bermanfaat. Masyarakat di Kelurahan Limbungan Kecamatan Rumbai Pesisir Kota Pekanbaru telah memiliki bank sampah, tetapi manfaatnya belum dirasakan oleh masyarat karena sampah anorganik masih dibuang. Perlu adanya upaya mensosialisasikan dan mengedukasi masyarakat untuk mengolah sampah anorganik menjadi produk kerajinan yang memiliki nilai ekonomis. Metode yang digunakan adalah penyuluhan kepada masyarakat tentang pengolahan sampah secara umum dan demonstrasi pemanfatan sampah plastik menjadi produk kerajinan. Setelah dilakukan penyuluhan, masyarakat telah memiliki pengetahuan tentang pengelolaan sampah secara umum dan ketrampilan dalam mengolah sampah anorganik berupa plastik menjadi produk kerajinan seperti tempat permen, tempat gelas dan tas yang layak digunakan dan layak dijual.
\end{abstract}

Kata Kunci : sampah anorganik, plastik, kerajinan tangan

\section{PENDAHULUAN}

Permasalahan sampah merupakan masalah yang dihadapi di kota besar, termasuk Kota Pekanbaru. Bertambahnya jumlah penduduk setiap tahunnya dan perubahan terhadap pola konsumsi dan gaya hidup masyarakat mengakibatkan semakin bertambahnya jenis, jumlah dan keragaman sampah yang dihasilkan setiap harinya. Berdasarkan undang-Undang Republik Indonesia Nomor 18 Tahun 2008 (2008) menyatakan sampah merupakan bahan yang berasal dari kegiatan manusia yang tidak digunakan lagi. Menurut Soewedo (1983) dalam Fatoni et al., (2017) sampah berdasarkan sifatnya dikategorikan menjadi sampah anorganik dan organik. Sampah anorganik merupakan sampah yang berasal dari kegiatan/aktivitas manusia yang sukar terurai oleh mikroorganime dan membutuhkan jangka waktu yang panjang dalam proses penguraiannya. Sedangkan sampah organik adalah sampah yang berasal dari makhluk hidup yang mudah teruarai oleh mikroorganisme. 
Menurut Marliani (2015) sampah yang berasal dari rumah tangga memberikan kontribusi tersebar di daerah perkotaan yang didominaasi $75 \%$ berupa sampah organik sisanya berupa sampah anorganik. Tingginya kontribusi sampah rumah tangga di daerah perkotaan mendorong upaya pengolahan sampah dengan tujuan meningkatkan nilai sampah dari sesuatu yang tidak bermanfaat menjadi bernilai ekonomis. Disamping itu kualitas lingkungan dapat ditingkatkan sehingga kesehatan masyarakat tetap terjaga. Pada umumnya masyarakat melakukan pengolahan sampah dengan cara mengumpulkan, membuang dan mengangkut ke TPA. Perlu adanya pergeseran paradigma pengolahan sampah dengan cara mengurangi sampah, menggunakan dan memakai kembali serta mendaur ulang dengan menggunkan prinsip $3 \mathrm{R}$ (reduce, reuse dan recyle). Dengan prinsip 3R maka sampah yang belum memiliki nilai ekonomis dan tidak ramah lingkungan dapat diolah menjadi barang yang bermanfaat, bernilai ekonomis dan ramah lingkungan. Dalam pemanfataan dan pengolahan sampah perlu melibatkan berbagai komponen dalam masyarakat dengan memperhatikan karakteristik sampah, kondisi lingkungan dan karaktestik sosial budaya masyarakat (Marliani, 2015). Sampah merupakan barang yang terbuang dan tidak termanfaatkan dapat diolah menjadi produk yang bernilai ekonoomis (Suryani et al., 2019).

Sebagian besar sampah organik telah diolah menjadi kompos dan biogas, sedangkan sampah anorganik masih sulit pengolahannya karena tidak mudah didegradasi oleh alam. Jenis sampah anorganik banyak dijumpai adalah jenis plastik khususnya botol plastik (Purnama \& Yuriandala, 2010). Langkah yang paling awal dapat dilakukan rumah tangga dalam rangka pengolahan sampah adalah dilakukan pemilahan sampah organik dan anorganik. Sampah organik dpat diolah menjadi kompos sedangkan sampah anorganik dapat diolah menjadi produk kerajinan tangan (Devi, 2016). Selain diolah menjadi produk kerajinan, sampah anorganik berupa plastik dapat diolah menjadi paving block yang dapat digunakan untuk jalan setapak dan hiasan rumah (Luthfianto dan Nurkhanifah , 2020)

Kelurahan Limbungan terletak di Kecamatan Rumbai Barat Kota Pekanbaru dengan luas wilayah 3,5 m², 12 RW, 51 RT, jumlah penduduk 11.875 jiwa. Kelurahan Limbungan sudah memiliki bank sampah tetapi keberadaannya belum dirasakan maksimal oleh masyarakat. Rendahnya kesadaran masyarakat untuk menyetorkan sampah anorganik ke bank sampah karena sampah dianggap sesuatu yang tidak bermanfaat dan tidak bernilai ekonomis. Kebiasaan membakar sampah dan membuangnya ke TPA menyebabkan pencemaran air, tanah dan udara. Sebagian kecil masyarakat telah mengolah organik menjadi kompos karena telah dilakukan kegiatan sosialisasi dan pelatihan pembuatan kompos. Sedangkan untuk sampah anorganik masyarakat cenderung membuangnya. Kondisi ini dapat dikurangi dengan menumbuhkan kesadaraan masyarat untuk memilah sampah dan mengolah kembali sampah anorganik yang bisa dimanfaatkan menjadi tas, tempat tissue, tempat gelas, piring dll. yang bernilai ekonomi. Selama ini belum ada sosialisasi dan edukasi tentang pemanfaatan sampah anorganik menjadi produk kerajinan sehingga masyarakat tidak memanfaatkan sampah anorganik menjadi produk yang bernilai ekonomi.

Universitas Lancang Kuning melalui Tim Pengabdian Masyarakatnya memiliki pengetahuan untuk mengolah sampah anorganik menjadi produk kerajinan yang memiliki nilai ekonomis. Sehingga kegiatan ini dijadikan sebagai sarana untuk mentransfer pengetahuan yang dimiliki ke khalayak umum yang membutuhkan. Berdasarkan kegiatan yang dilakukan oleh Sulistyorini (2005) dilaporkan bahwa transfer teknologi kepada masyarakat dapat meningkatkan pengetahuan mereka dalam mengolah sampah menjadi lebih berguna.

Tujuan kegiatan ini adalah memberikan sosialisasi dan edukasi pemanfaataan sampah anorganik kepada masyarakat serta memberikan ketrampilan untuk memproduksi produk kerajinan yang bernilai ekonomis. Dengan adanya kepedulian, kesadaran dan ketrampilan yang dimiliki oleh masyarakat maka sampah anorganik dapat diolah menjadi produk yang bermanfaat dan mampu dipasarkan sehingga dapat meningkatkan perekonomian keluarga. 


\section{METODE}

Pemberdayaaan masyarakat dalam pemanfaatan sampah anorganik dilaksanakan di Kelurahan Limbungan, Kecamatan Rumbai Pesisir. Peserta sebanyak 20 orang yang berasal dari pengurus Bank Sampah Berkah Abadi dan masyarakat di sekitarnya. Kegiatan dimulai dengan meninjau secara langsung kondisi eksisting wilayah mitra kemudian dilanjutkan dengan menumbuhkan kesadaraan mitra tentang pentingnya mengolah sampah dilihat dari aspek lingkungan dan dan ekononi keluarga. Untuk menumbuhkan kesadaran ini dilakukan sosialisasi dan penyadaran dalam bentuk penyuluhan. Kemudian mitra dilatih dan diberi ketrampilan pemanfaatan sampah anorganik berupa gelas minuman plastik menjadi produk kerajinan seperti tas, tempat gelas, pot bunga, tempat tissue dll. Selain itu juga dilatih pembuatan tas dan alas meja berbahan dasar bungkus minuman sachet. Dilakukan pendampingan dan evaluasi kepada mitra untuk mengamati, menilai tingkat keberhasilan kegiatan dan memberikan solusi terhadap pemasalahan yang ditemui dalam mengolah sampah anorganik menjadi produk kerajinan.

\section{HASIL DAN PEMBAHASAN}

\subsection{Sosialisasi dan Pemberdayaan Masyarakat}

Kegiatan pemberdayaan masyarakat dalam mengolah sampah anorganik diikuti antusias oleh masyarakat ditunjukkan dengan partisipasi kehadiran peserta $100 \%$. Sosialisasi bertujuan untuk memberi pengetahuan kepada masyarakat tentang pentingnya mengelola sampah secara umum, baik dari aspek kesehatan, lingkungan dan pendapatan keluarga. Penyampaian materi sosialisasi menggunakan power point dan modul yang diberikan kepada peserta. Tahap awal yang diperkenalkan kepada mitra adalah bagaimana memilah sampah organik dan anorganik. Kemudian diberikan pengetahuan tentang perbedaan antara sampah organik dan anorganik dan bagaimana mengolahnya menjadi produk yang bermanfaat. Tim menekankan partisipasi yang dilakukan oleh masyarakat dengan mengurangi penggunaan sampah anorganik, mengolah sampah organik menjadi kompos dan mendaur ulang sampah anorganik menjadi produk yang bermanfaat dalam rangka meningkatkan kualitas lingkungan. Suasana kegiatan sosialisasi dapat dilihat paada gambar 1.

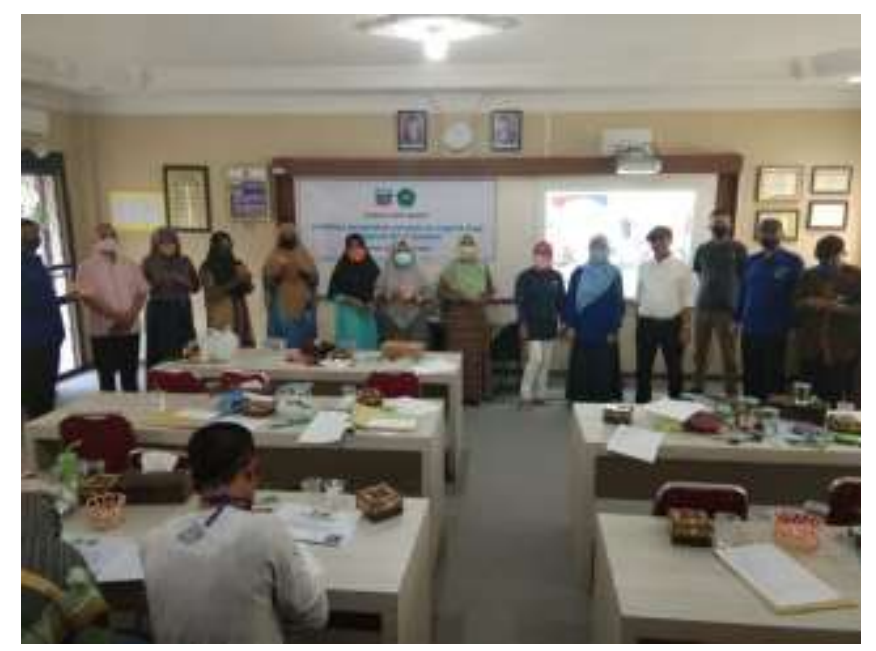

Gambar 1. Kegiatan Sosialissi Pengolahan Sampah anorganik

Materi sosialiasi juga difokuskan terhadap pengolahan sampah anorganik berupa sampah kertas, kaleng dan botol, plastik dan sampah kain. Sebagian peserta ternyata baru menyadari penggunaan sampah anorganik berupa plastik membutuhkan waktu yang sangat lama bagi mikoorganisme untuk menguraikannya, bisa sampai ratusan tahun. Peserta antusias mengikuti kegiatan sosialisasi, ditunjukkan banyaknya peserta yang bertanya dan menceritakan pengalamannya. 


\subsection{Pelatihan Pengolahan Sampah Plastik}

Setelah dilakukan sosialisasi tentang pentingnya pengolahan sampah secara umum dilanjutkan dengan pelatihan membuat aneka produk kerajinan dari sampah plastik. Aneka sampah plastik berupa limbah kemasan yang berasal dari sabun, pewangi pakaian, minumanan, permen, smpo dan plastik kresek telah dimanfaatkan oleh masyarakat Desa Aleu Lim menjadi menjadi tas dan dompet (Diana, Marliana, Z., \& Elwina., 2017).

Mitra antusias mengikuti kegiatan pelatihan, dibuktikan dengan tingkat partisipasi kehadiran $100 \%$. Bahan baku yang digunakan dalam pelatihan adalah sampah plastik yang dibawa oleh mitra seperti gelas minuman plastik, bungkus minuman sachet, detergen, dll. Sebelum sampah tersebut diolah terlebih dahulu sampah tersebut disterisaasi dengan cara mencuci dengan diterjen dan direndam beberapa saat dengan air hangat. Setelah sampah tersebut steril maka sampah bisa diolah menjadi produk kerajianan tangan.

Dalam kegiatan ini mitra diberi ketrampilan membuat dompet dari plastik kemasan dan tempat permen/minuman dari gelas minuman plastik. Untuk membuat dompet dari plastik terlebih dahulu dibuat anyaman dari bungkus mi instan dan kopi. Alat-alat yang digunakan berupa gunting kecil, benang dan jarum jahit. Adapun cara pembuatannya diawali dengan membersihkan kemasan mie instan kemudian merapikan bekas kemasan dengan menggunting bagian pinggir ujung atas dan ujung bawang. Setelah bekas kemasan dirapikan bagian pinggir atas dan bawah dilanjutkan dengan melipat bekas kemasan menjadi 3 bagian dengan bentuk lipatan disesuaikan dengan motif atau bagain dari dari kemasan yang ingin ditampilkan. Dengan menggunakan gunting dilakukan perapiaam dan menipiskan kemasan bekas. Kemudian lipatanlipatan bekas kemasan yang sudah terbentuk, dirangkaikan satu sama lainnya membentuk anyaman tas. Untuk memperkuat anyaman tas yang telah dibuat maka dilakukan penjaitan dengan menggunakan mesin jahit terhadap anyaman tersebut. Proses pembuatan tas dari sampah platik dapat dilihat pada gambar 2 .

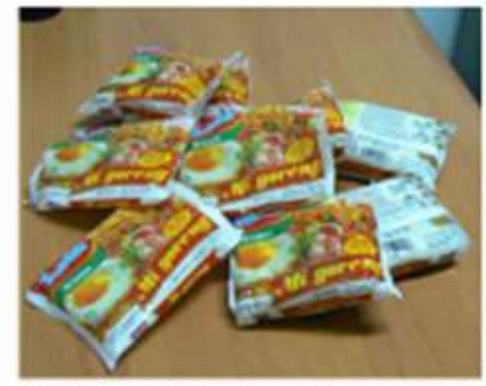

1. Bahan baku bungkus mi instan

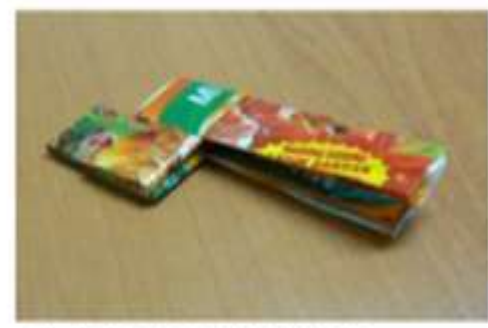

4, proses menganyam

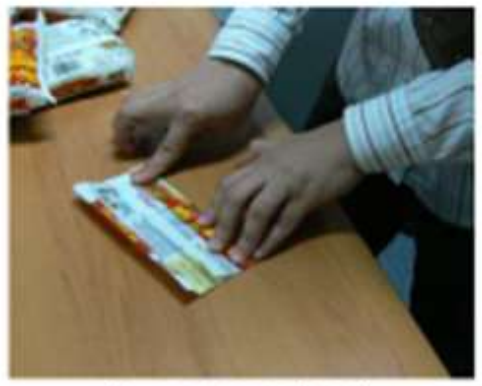

2. proses melipat

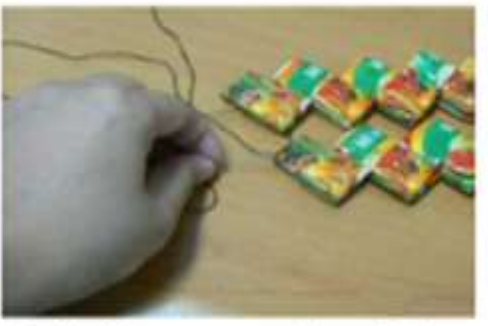

5. Hasil anyaman dirangkai dengan cara dijahit menggunakan benang.

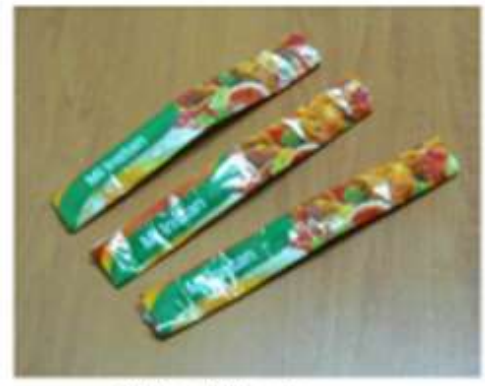

3. hasil lipatan

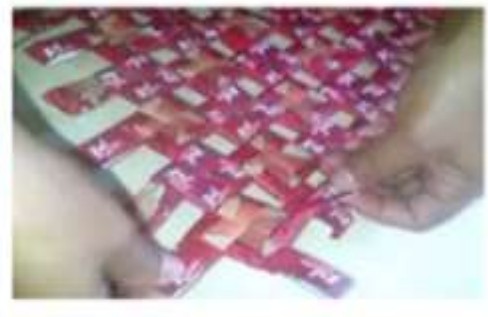

Gambar 2. Tahapan Pembuatan Tas Dari Sampah Plastik 
Produk lain yang dibuat dalam pelatihan ini adalah tempat permen/gelas yang berbahan dasar minuman gelas plastik. Dengan kemampauan adaftif yang tinggi terhadap penggunaan alat dan bahan yang ada, mitra mampu membuat aneka bentuk dari sampah minuman gelas plastik. Proses pembuatan tempat permen dapat dilihat pada gambar 3.

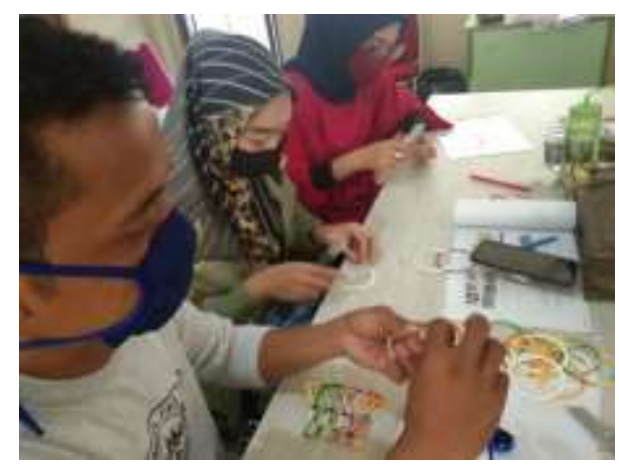

(a)

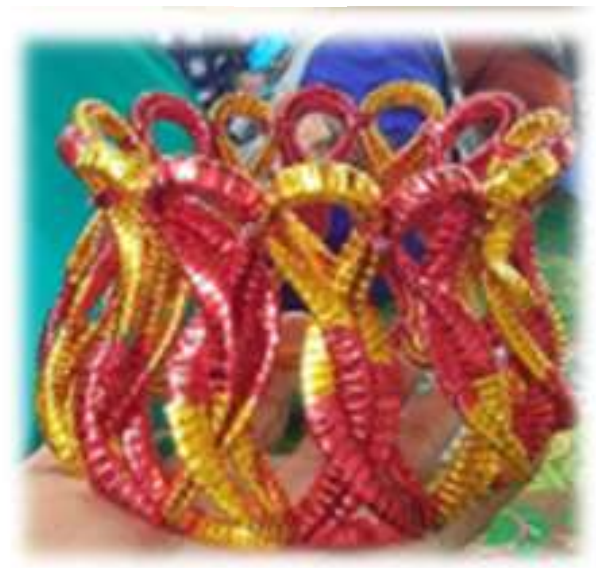

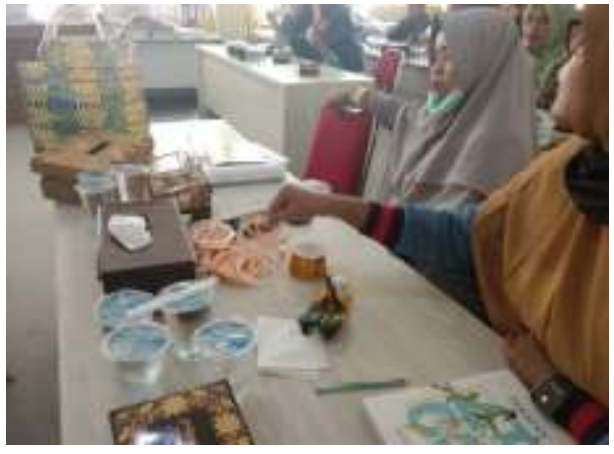

(b)

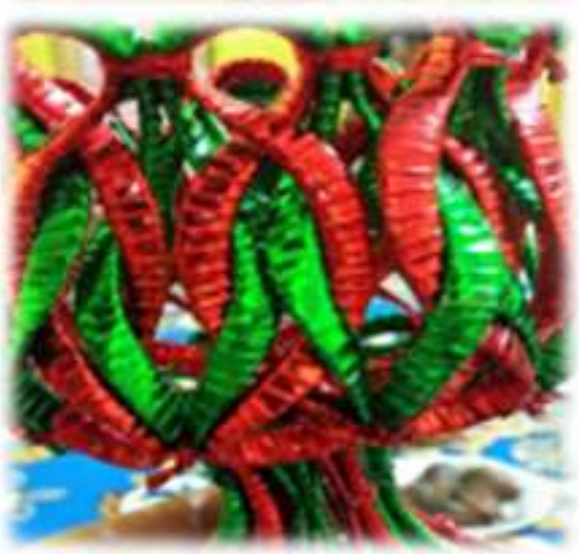

(c)

Gambar 3. Proses Pembuatan (a), (b) dan Produk (c) Kerajinan Dari Sampah Minuman Gelas Plastik

\subsection{Pendampingan dan Evaluasi Kegiatan}

Kegiatan pendampingan dilakuan selama kegiatan pelatihan sedang berlangsung dengan tujuan untuk mengetahui ketrampilan mitra dalam membuat produk kerajinan. Berdasarkan hasil evaluasi dari kegiatan pelatihan diketahui mitra telah memiliki ketrampilan dalam memanfaatkan sampah anorganik menjadi tas, gelas, dompet dll. Untuk mengetahui keberlanjutan dari kegiatan pelatihan yang telah diberikan, tim juga melakukan kunjungan ke mitra untuk mengetahui kendala yang dihadapi. Mitra telah memiliki kretivitas yang tinggi dalam mengolah sampah plastik menjadi produk yang memiliki nilai ekonomis. Produk olahan sampah plastik dapat diihat pad gambar 4. 


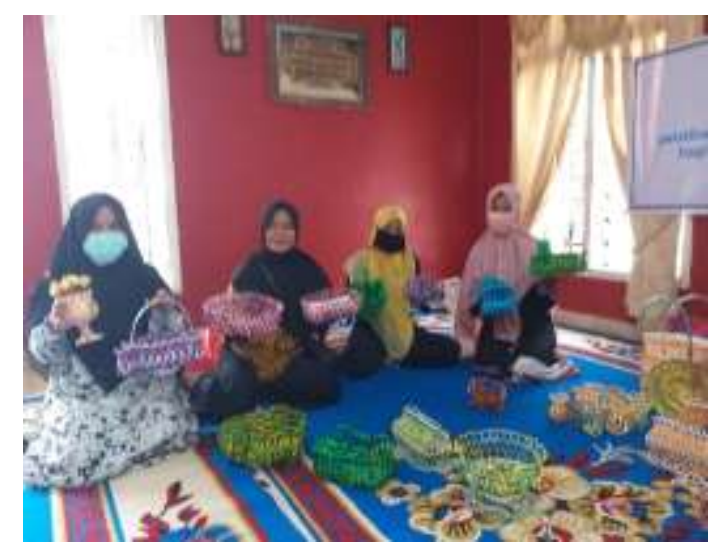

(a)

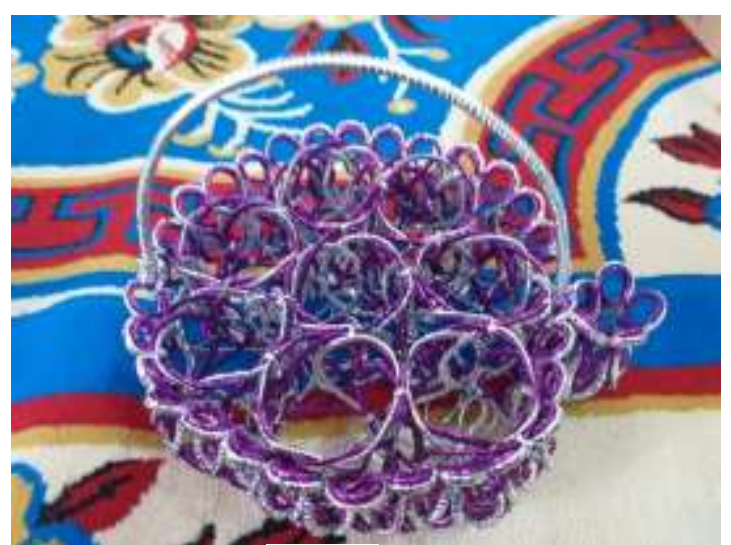

(b)

Gambar 4. Aneka Produk kerajinan dari sampah plastik

Pada saat ini kendala yang dihadapi oleh mitra adalah pemasaran produk karena belum adanya produk yang terjual. Produk kerajinan yang dihasilkan hanya dipakai sendiri untuk keluarga. Menurut Setiorini (2018) menyatakan dengan mengadakan pelatihan pemanfaatan barang bekas yang sudah tidak digunakan dapat memberikan pengalaman tersendiri bagi ibu rumah tangga dengan cara pemanfaatan barang bekas menjadi layak pakai dan juga untuk menambah perekonomian keluarga.

\section{KESIMPULAN}

Masyarakat di Kelurahan Limbungan, Kecamatan Rumbai Pesisr telah memiliki pengetahuan tentang pengelolaan sampah secara umum dan ketrampilan dalam mengolah sampah anorganik berupa plastik menjadi produk kerajinan yang layak digunakan dan layak dijual. Perlu adanya kegiatan lanjutan untuk pemasaran produk kerajinan sehingga nilai ekonomi dari sampah anorganik dapat dirasakan oleh masyarakat.

\section{UCAPAN TERIMA KASIH}

Tim kegiatan ini mengucapan terima kasih disampaikan kepada PT Cevron Pacific Indonesia yang telah membantu pendanaan dalam kegiatan pemberdayaaan masyarakat dalam mengolah sampah. Ucapan terima kasih juga disampaikan kepada Lembaga Penelitian dan Pengabdian Kepada Masyarakat Universitas Lancang Kuning yang telah memfasilitasi sehingga kegiatan ini dapat berjalan sesuai dengan target dan tujuan yang direncanakan.

\section{DAFTAR PUSTAKA}

Devi, A. (2016). Meningkatkan Pemahaman Masyarakat Melalui Sosialisasi Persampahan dan Rumah Sehat di Permukiman Tempat Pembuangan Akhir (Tpa) Desa Neglasari, Tangerangangerang. Jurnal Abdimas, 2(2), 12-17.

Diana, S., Marliana, Z., A., \& Elwina. (2017). Pemanfaatan Sampah Plastik Menjadi Produk Kerajinan Tangan Bernilai Ekonomis Bagi Remaja Putus Sekolah. Jurnal Hasil-hasil penerapan IPTEKS dan Pengabdian Kepada Masyarakat 1 (1) : 68-73, 1(1), 68-73.

Fatoni, N., Imanuddin., R., \& Darmawan, A. . (2017). Pendayagunaan Sampah Menjadi Produk

Kerajinan. Dimas: Jurnal Pemikiran Agama untuk Pemberdayaan, 17(1), 83. https://doi.org/10.21580/dms.2017.171.1505

Luthfianto, S., \& Nurkhanifah, N. (2020). Inovasi Limbah Plastik dan Kulit Kopi Menjadi Paving 
Block di Desa Penakir Pemalang. Dinamisia: Jurnal Pengabdian Kepada Masyarakat, 4(1), 176185.

Marliani, N. (2015). Pemanfaatan Limbah Rumah Tangga (Sampah Anorganik) Sebagai Bentuk Implementasi dari Pendidikan Lingkungan Hidup. Formatif: Jurnal Ilmiah Pendidikan MIPA, 4(2), 124-132. https://doi.org/10.30998/formatif.v4i2.146

Purnama, H., \& Yuriandala, Y. (2010). Studi Pemanfaatan Sampah Plastik Menjadi Produk dan Jasa Kreatif, 2, 21-31.

Setiorini, I. L. (2018). Pemanfaatan Barang Bekas Menjadi Kerajinan Tangan Guna Meningkatkan Kreativitas Masyarakat Desa Paowan. Integritas : Jurnal Pengabdian, 2(1), 53-61.

Sulistyorini, L. (2005). Pengelolaan Sampah Dengan Cara Menjadikannya Kompos Lilis. J. Kesehatan Lingkungan, 2(1), 77-85.

Suryani, L., Aje, A. U., Tute, K. J., Flores, U., Studi, P., Informatika, S., ... Universitas, I. (2019). Kabupaten Ende Dalam Pegelolaan Limbah Organik dan Anorganik Berbasis 3r Untuk Mengeskalasi Nilai. Dinamisia: Jurnal Pengabdian Kepada Masyarakat, 3(2), 1-8.

Undang-Undang Republik Indonesia Nomor 18 Tahun 2008. (2008). Undang-Undang Republik Indonesia Nomor 18 Tahun 2008 Tentang Pengelolaan Sampah, 1-27. 